\title{
KEGIATAN PENGEMBANGAN KOLEKSI PERPUSTAKAAN KINERUKU
}

\author{
Zenza Ramadhan Natapraja \\ Dian Sinaga \\ Andri Yanto \\ Program Studi Ilmu Perpustakaan Fakultas Ilmu Komunikasi \\ Jl. Raya Bandung Sumedang Km. 21 Sumedang 45363 \\ Universitas Padjadjaran \\ Email: zensanatapraja@gmail.com
}

\begin{abstract}
ABSTRAK
Perpustakaan Kineruku adalah salah satu perpustakaan pribadi yang dikelola secara pribadi berletak di Kota Bandung dan didirikan oleh Ariani Darmawan. Penelitian ini bertujuan untuk mengetahui kebijakan Perpustakaan Kineruku mengenai kegiatan pengembangan koleksi serta mengetahui proses kegiatan pengembangan koleksi di Perpustakaan Kineruku. Penelitian ini menggunakan metode penelitian kualitatif dengan pendekatan studi kasus. Penelitian ini merujuk pada teori pengembangan koleksi oleh Edward G. Evans. Teknik pengumpulan data dilakukan dengan cara wawancara, observasi, studi dokumentasi, dan triangulasi. Hasil dari penelitian menunjukkan bahwa Perpustakaan Kineruku tidak memiliki kebijakan tertulis melainkan kesepakatan bersama antar pemilik dan pengurus Perpustakaan Kineruku.
\end{abstract}

Kata Kunci: Pengembangan Koleksi, Kebijakan Pengembangan Koleksi, Proses Pengembangan Koleksi, Perpustakaan Pribadi, Perpustakaan Kineruku.

\begin{abstract}
Kineruku's library is one of the personal library located in Bandung and was founded and personally run by Ariani Darmawan. This study aims to determine the policy of the Kineruku's library regarding collection development activities and to discover the process of collection development activities in the Kineruku's library. This study uses qualitative research methods with a case study approach. This research refers to the theory of collection development by Edward G. Evans. The data collection techniques are done by interview, observation, documentation study, and triangulation. The results of the study show that the Kineruku's library does not have a written policy but rather a joint agreement between the owner and management of the Kineruku's library.
\end{abstract}

Keywords: Pengembangan Koleksi, Kebijakan Pengembangan Koleksi, Proses Pengembangan Koleksi, Perpustakaan Pribadi, Perpustakaan Kineruku. 


\section{PENDAHULUAN}

Perpustakaan Kineruku adalah salah satu perpustakaan pribadi yang dikelola secara pribadi berletak di Kota Bandung dan didirikan oleh Ariani Darmawan. Perpustakaan ini berdiri setelah Ariani mendapatkan ide untuk mendirikan dan mengelola sebuah perpustakaan, ide ini muncul ketika Ariani melaksankan studi di Amerika Serikat pada saat itu beliau melihat betapa akses publik terhadap informasi di negeri maju sangat terfasilitasi, terlihat dari banyaknya perpustakaan kota, toko-toko buku, toko CD musik, dan rental film di setiap penjuru kota. Sepulangnya ke Indonesia, dengan ide yang beliau dapat disana dan percaya pada pepatah 'Knowledge Is Power' beliau segera merealisasikan idenya membuat sebuah ruang akses informasi publik di sebuah rumah kosong peninggalan kakeknya dan lahirlah 'Rumah Buku’ di tahun 2003.

Berawal dari 'Rumah Buku'. Ariani bersama rekannya, Oky Kusprianto, bertekad untuk menciptakan Rumah Buku sebagai perpustakaan dengan tingkat kenyamanan layaknya rumah sendiri. Kemudian pada tahun 2005 berganti nama menjadi 'Kineruku' karena ternyata nama 'Rumah Buku' sudah ada yang menggunakan. Arti nama 'Kineruku' di ambil dari kata "Kine" yang merujuk ke kata "Sinema" dan "ruku" yang merupakan singkatan dari "Rumah Buku" dan nama 'Kineruku' awalnya adalah nama salah satu program menonton film di perpustakaan tersebut. 'Kineruku' memiliki 3 (tiga) inti sebagai bentuk pondasi utama mereka yaitu : buku, musik dan, film. Berdasarkan dari ketiga inti tersebut pemilik menciptakan slogan “baca, dengar, tonton”.

Perpustakaan Kineruku didirikan dengan semangat berbagi sebagai alternatif pusat referensi buku, musik dan, film dimana publik bisa mengaksesnya dengan mudah selain itu untuk mengubah anggapan sebagian kalangan bahwa perpustakaan adalah tempat yang angker, kurang bersahabat serta kegiatan yang bisa dilakukan hanyalah membaca dan meminjam buku saja konsep interior Kineruku dibuat seperti rumah sofa, kursi yang disusun rapih, dan ruang diskusi menjadi fasilitas pendukung desain interiornya serta eksterior taman hijau yang asri, banyak 
pengunjung yang akhirnya menganggap Kineruku sebagai rumah kedua mereka karena desain interior serta eksteriornya.

Beberapa kali peneliti berkunjung ke perpustakaan yang terletak di Jalan Hegarmanah No. 52, Bandung ini peneliti melihat koleksi buku, musik, dan film yang Kineruku miliki dan membuat peneliti cukup tertarik dengan apa yang Perpustakaan Kineruku terapkan pada koleksi-koleksinya. Koleksi buku, album-album lagu dan film-film yang disusun rapih, diberi sampul, dan diberi label warna dengan maksud memudahkan pemustaka untuk mencari koleksi dan memenuhi kebutuhan informasi yang Perpustakaan Kineruku berikan. Satu hari peneliti bertemu mas Budi Warsito, beliau merupakan pengelola Perpustakaan Kineruku dan peneliti pun bertanya apakah Perpustakaan Kineruku sudah menggunakan sistem pengembangan koleksi? Dan beliau menjawab "Kami tidak menggunakan sistem yang terpaku seperti PERPUSNAS atau perpustakaan yang dibentuk suatu lembaga ya, tidak terpaku pada teori hanya sebatas inisiatif kami untuk memberi label warna, sampul, dan menjalankan apapun agar koleksi-koleksi yang kami miliki itu terawat dan dapat dibaca oleh pemustaka".

Berawal dari hanya 300 koleksi kini Perustakaan Kineruku sudah memiliki kurang lebih 5000 koleksi yang semuanya ada dalam ranah ilmu humaniora seperti sejarah, seni, desain, sastra, sinematografi, dan lainnya. Sudah hampir 15 tahun Perpustakaan Kineruku hadir membantu serta memudahkan publik untuk mengakses informasi sejak pertama kali di aktifkan pada tahun 2003. Hal ini membuat pemilik terus mengembangkan Perpustakaan Kineruku sebagai ruang akses informasi publik yang tak hanya memberikan kenyamanan, koleksi yang lengkap, akses informasi yang cepat dan akurat, tetapi juga apresiasi terhadap koleksi yang dimiliki dengan cara dilakukannya kegiatan pengembangan koleksi.

Saat ini Perpustakaan Kineruku melaksanakan kegiatan pengembangan koleksi yang terbilang tidak terpaku pada teori yaitu analisis pemustaka yang digunakan oleh Perpustakaan Kineruku seperti menanyakan langsung kepada pemustaka untuk mendapatkan timbal balik tentang Kineruku, 
melihat dan merespon jejaring sosial Kineruku (Facebook, Twitter, Instagram, dan lain-lain.)

Kebijakan pengembangan koleksi yang diterapkan di Perpustakaan Kineruku hanya sebatas pemahaman pemiliknya, tanpa ada pengetahuan terkait pengembangan koleksi. Pengadaan koleksi sendiri Perpustakaan Kineruku sampai saat ini diperoleh dari sumbangan rekan-rekan pemilik dan dari hasil pembelian pribadi pemilik tersebut.

Berkaitan dengan kegiatan penyiangan di Perpustakaan Kineruku, dimulai ketika ada koleksi baru yang masuk lalu dilakukan inspeksi apakah ada kerusakan atau tidak, contoh nyatanya apabila ada kerusakan hal yang Kineruku bisa lakukan adalah memperbaiki dengan selotip atau mengganti koleksi tersebut dengan koleksi cadangan yang disimpan, tergantung tingkat kerusakannya. Koleksi yang sudah ada pun kurang lebih sama penanganannya.

Pengembangan koleksi merupakan salah satu dari banyaknya kegiatan yang ada di dalam suatu perpustakaan, pengembangan koleksi mencakup semua kegiatan untuk memperluas koleksi yang ada di perpustakaan tersebut terutama yang berkaitan dengan pemilihan dan evaluasi, hal ini pun berlaku di Perpustakaan Kineruku. Menurut ALA Glossary of Library and Information Science (1983) dalam Yulia dan Sujana (2009) pengertian pengembangan koleksi adalah:

"A term which encompasses a number of activities related to the development of the library collection, including the determination of the library collection including the determination and coordination of selection policy, assessment of needs of users and potential users, collection evaluation, identification of collection needs, selection of materials, planning for resource sharing, collection maintenance, and weeding".

Sehingga dari kutipan tersebut dapat disimpulkan bahwa pengembangan koleksi perpustakaan termasuk penentuan koleksi perpustakaan, penentuan dan koordinasi kebijakan seleksi, penilaian kebutuhan pemustaka dan calon pemustaka, evaluasi koleksi, identifikasi kebutuhan koleksi, pemilihan bahan, perencanaan untuk berbagi sumber daya, pemeliharaan koleksi, serta penyiangan. 
Menurut Evans (2005) dalam pengembangan koleksi terdapat enam tahap kegiatan utama yaitu, (1) Analisis Pemustaka, (2) Kebijakan Pengembangan Koleksi, (3) Pemilihan Koleksi, (4) Pengadaan Koleksi, (5) Penyiangan dan, (6) Evaluasi. Alur dari keenam tahap kegiatan utama pengembangan koleksi dimulai dari analisis pemustaka kemudian berlanjut ke kebijakan koleksi, pemilihan koleksi, pengadaan koleksi, penyiangan dan, evaluasi. Ketika tahap evaluasi sudah tuntas proses tersebut akan dimulai kembali dari tahap analisis pemustaka.

Setiap perpustakaan pastinya memiliki tujuan untuk memenuhi kebutuhan informasi bagi pemustakanya, salah satu cara untuk mencapai tujuan tersebut yaitu dengan cara melaksanakan kegiatan pengembangan koleksi, dalam pelaksanaannya pun memerlukan kebijakan-kebijakan yang mengatur kegiatan pengembangan koleksi. Atas dasar hal tersebut peneliti tertarik untuk melakukan penelitian terkait bagaimana pengembangan Koleksi. Adapun Rumusan masalah dari penelitian ini adalah "Bagaimana kegiatan pengembangan koleksi di Perpustakaan Kineruku?". Berdasarkan rumusan masalah tersebut, didapat tujuan penelitian yang dapat dijelaskan ke dalam beberapa poin: Untuk mengetahui kebijakan Perpustakaan Kineruku mengenai kegiatan pengembangan koleksi; Untuk mengetahui proses analisis pemustaka di Perpustakaan Kineruku; Untuk mengetahui proses kebijakan seleksi di Perpustakaan Kineruku; Untuk mengetahui proses seleksi di Perpustakaan Kineruku; Untuk mengetahui proses pengadaan bahan pustaka di Perpustakaan Kineruku; Untuk mengetahui proses penyiangan di Perpustakaan Kineruku; Untuk mengetahui proses evaluasi di Perpustakaan Kineruku.

\section{METODE}

Metode yang digunakan dalam penelitian ini adalah metode kualitatif. Menurut Moleong (2007) penelitian kualitatif adalah suatu bentuk penelitian yang bermaksud untuk memahami suatu fenomena tentang apa yang dialami oleh subjek penelitian misalnya perilaku, persepsi, tindakan dan lain-lain dengan cara deskripsi dalam bentuk kata - kata dan bahasa, 
pada suatu konteks khusus yang alamiah dan dengan memanfaatkan berbagai metode alamiah.

Penelitian ini menggunakan pendekatan studi kasus. Studi kasus bertujuan untuk menggambarkan secara cermat karakteristik dari suatu gejala atau masalah yang diteliti. Menurut Yin (2008) bukti atau data untuk keperluan studi kasus bisa berasal dari 6 (enam) sumber, yaitu: dokumen, rekaman arsip, wawancara, pengamatan langsung (observasi non partisipasi), observasi partisipan, dan perangkat-perangkat fisik. Penggunaan keenam sumber ini memerlukan keterampilan dan prosedur metodologis yang berbeda-beda, serta strategi yang lebih cocok bila pokok pertanyaan suatu penelitian berkenaan dengan how dan why. Bila peneliti hanya memiliki sedikit peluang untuk mengontrol peristiwa-peristiwa yang akan diselidiki, dan apabila fokus penelitiannya terletak pada fenomena kontemporer (masa kini) di dalam konteks kehidupan nyata.

Alasan peneliti menggunakan metode kualitatif dengan pendekatan studi kasus karena penelitian ini merupakan penelitian yang mendalam tentang satu organisasi, satu program kegiatan dalam waktu tertentu. Tujuannya untuk memperoleh deskripsi yang utuh dan mendalam. Proses penelitian kualitatif ini melibatkan upaya-upaya penting, seperti mengajukan prosedur dan pertanyaan, mengumpulkan data yang spesifik dari para partisipan, menganalisis data secara induktif mulai dari tema yang khusus ke tema yang umum, dan menafsirkan makna data.

Teknik pemilihan informan yang digunakan adalah purposive sampling. Purposive sampling merupakan teknik pengambilan sampel sumber data dengan pertimbangan tertentu. Pertimbangan tersebut yaitu seseorang yang dianggap paling tahu tentang apa yang kita harapkan, atau seorang ahli dalam bidang yang sedang diteliti (Yin, 2014). Kriteria yang dibutuhkan peneliti adalah informan yang memahami dan terlibat dalam pengembangan koleksi di Perpustakaan Kineruku. Selain itu kriteria informan yang dibutuhkan oleh peneliti adalah anggota atau pengurus Perpustakaan Kineruku dan berperan aktif dalam proses pengembangan koleksi di 
Perpustakaan Kineruku. Subjek dari penelitian ini adalah pengurus sekaligus pemilik dari Perpustakaan Kineruku, Bapak Budi Warsito dan informan untuk penelitian ini adalah aktivis literasi, Bapak Edi Dimyati.

Peneliti menggunakan observasi langsung, wawancara, dan rekaman arsip sebagai prosedur-prosedur pengumpulan data penelitian. Teknik analisis data yang peneliti lakukan yaitu teknik penjodohan pola. Membandingkan teori pengembangan koleksi dengan data yang diperoleh dari lapangan yang sudah dicari dan disusun secara sistematis seperti hasil wawancara dengan pengelola Perpustakaan Kineruku dan observasi langsung, setelah itu peneliti mengorganisasikan data yang di dapat ke dalam kategori tertentu, menjabarkannya, menyusun menjadi sebuah pola, memilah antara data yang akan diperlukan dan dipelajari, untuk kemudian dibuat kesimpulan akhir sehingga mudah untuk dipahami oleh pembaca.

Untuk uji keabsahan data hasil penelitian, peneliti menggunakan triangulasi, Triangulasi merupakan teknik yang menggabungkan dari berbagai teknik-teknik pengumpulan data dan sumber data yang telah ada. Triangulasi sumber data difokuskan pada kebijakan dan proses pengembangan koleksi di Perpustakaan Kineruku. Bentuk data untuk triangulasi berupa hasil wawancara mendalam dengan pengelola Perpustakaan Kineruku dan bentuk kajian literatur terkait dengan topik penelitian. Informan dalam triangulasi penelitian ini adalah memiliki pemahaman lebih terkait dengan pengembangan koleksi. Disebutkan triangulasi karena pengujian dilakukan berdasarkan hal berikut, yaitu triangulasi teori pengembangan koleksi dari Edward Evans dan triangulasi sumber data dari informan di lapangan. 


\section{HASIL DAN PEMBAHASAN}

\section{Kebijakan Pengembangan Koleksi di Perpustakaan Kineruku}

Perpustakaan Kineruku tidak memiliki kebijakan pengembangan koleksi secara tertulis. Pemilik dan juga pengurus Perpustakaan Kineruku hanya melakukan diskusi informal dan rapat formal dengan staf yang diakhiri dengan poin-poin kesepakatan bersama yang tidak tertulis. Apabila ada poin dari kebijakan tersebut yang terlupakan baik itu oleh pemilik, pengurus atau staf penanganannya adalah dengan saling mengingatkan satu sama lain.

Serta yang dimaksud pengurus "sederhana" adalah Perpustakaan Kineruku bergerak secara otodidak tentang pengembangan koleksinya dimana tidak menggunakan prosedur pengembangan koleksi seperti standar perpustakaan pada umumnya.

Pengembangan koleksi Perpustakaan Kineruku yang tidak memiliki dokumen tertulis terkait kebijakan pengembangan koleksi dikarenakan jenis Perpustakaan Kineruku merupakan perpustakaan pribadi sehingga kebijakan pengelolaan bergantung pada pemilik dan tanpa menggunakan prosedur baku sebagaimana perpustakaan pada umumnya.

Kebijakan pada perpustakaan pribadi tidak dalam bentuk tertulis melainkan menggunakan kesepakatan bersama atau komitmen dan bersifat sangat fleksibel sesuai dengan situasi dan kondisi yang terjadi pada perpustakaan tersebut. Hal ini dikuatkan oleh Dimyati (2019) yang menyebutkan bahwa:

"Kebijakan secara tertulis tidak ada. Untuk pengembangan koleksi mengalir saja menyesuaikan dengan keinginan dari pembaca dan tema-tema buku yang sedang ramai dibicarakan dalam berita. Yang membuat kebijakan saya sendiri. Poinnya buku yang harus dimiliki oleh Kampung Buku adalah yang dicari oleh pembaca, buku yang diadaptasi ke layar lebar dan temanya kekinian".

Hal ini bertentangan dengan prosedur pengembangan koleksi yang ada pada perpustakaan pada umumnya sesuai dengan teori yang diungkapkan Evans dalam Winoto, Sinaga dan Rohanda (2018) yang menyatakan bahwa kebijakan pengembangan koleksi adalah merupakan rumusan atau 
dokumen tertulis yang memberi arah dan bimbingan mengenai koleksi yang akan dikembangkan.

Sehingga dapat dikatakan bahwa pada jenis perpustakaan pribadi tidak memiliki dokumen kebijakan dalam kegiatan pengembangan koleksi karena kebijakan pengelolaan bergantung pada pemilik dan tanpa menggunakan prosedur baku sebagaimana perpustakaan pada umumnya serta bersifat sangat fleksibel sesuai dengan situasi dan kondisi yang terjadi pada perpustakaan tersebut. Hal ini pun berlaku di Perpustakaan Kineruku.

\section{Analisis Pemustaka di Perpustakaan Kineruku}

Analisis pemustaka di Perpustakaan Kineruku dilakukan menggunakan metode mengumpulkan data berupa saran dan masukan dari pemustaka yang diterima oleh staf atau pengurus yang nantinya data-data tersebut disampaikan dan dibahas dalam rapat formal dengan pemilik Perpustakaan Kineruku.

Berdasarkan hal tersebut, kegiatan analisis pemustaka di Perpustakaan Kineruku yang hanya dengan mengumpulkan data berupa saran dan masukan dari pemustaka dalam hal ini dapat dikatakan bahwa metode analisis pemustaka tersebut tergolong kedalam metode analisis pemustaka secara informal dikarenakan jenis Perpustakaan Kineruku merupakan perpustakaan pribadi sehingga analisis pemustaka dilakukan oleh staf atau pengurus yang bukan ahli di bidang analisis pemustaka.

Kemudian didukung dengan hasil observasi, pertimbangan Perpustakaan Kineruku melakukan kegiatan analisis pemustaka dengan menggunakan metode informal karena faktor keterbatasan dana dan waktu sehingga tidak memungkinkan untuk melakukan analisis pemustaka dengan metode formal.

Hal ini sejalan dengan pernyataan Evans dalam Winoto, Sinaga dan Rohanda (2018) yang mengemukakan bahwa analisis pemustaka dapat dilakukan melalui dua cara yakni secara formal dan secara informal. Secara formal analisis pemustaka dapat dilakukan dengan cara membentuk tim riset untuk melakukan kajian ilmiah tentang pengguna perpustakaan. 
Secara informal, analisis pemustaka dilakukan dengan menerima masukan dari pemustaka dan pihak-pihak lainnya baik secara lisan maupun tertulis berkaitan dengan koleksi yang dibutuhkan.

Sehingga dapat dikatakan bahwa kegiatan analisis pemustaka di perpustakaan pribadi dilakukan menggunakan metode informal dikarenakan faktor ketersediaan dana dan waktu menjadi faktor penghambat utama perpustakaan pribadi dalam melakukan kegiatan pengembangan koleksi. Metode informal tidak memerlukan biaya besar serta dapat dilakukan oleh staf atau petugas kapan saja. Hal ini pun berlaku di Perpustakaan Kineruku.

\section{Kebijakan Seleksi di Perpustakaan Kineruku}

Perpustakaan Kineruku tidak memiliki dokumen kebijakan seleksi secara khusus melainkan hanya berbentuk kesepakatan bersama berbentuk poin-poin kriteria dan kriteria tersebut dibagi kedalam dua waktu koleksi, kriteria untuk koleksi yang sudah ada dengan koleksi yang akan datang. Tahapan kebijakan seleksi dimulai dengan diskusi informal antara pemilik yang nantinya hasil diskusi ini disampaikan dan dibahas dalam rapat formal membahas mengenai masukan mengenai koleksi dari pemustaka kemudian masukan tersebut dipertimbangkan untuk masuk ke dalam tahap seleksi.

Kebijakan seleksi di perpustakaan pribadi tidak dalam bentuk tertulis melainkan menggunakan kesepakatan bersama yang dibuat oleh pemilik perpustakaan tersebut. Hal ini dikuatkan oleh Dimyati (2019) yang merupakan seorang aktivis literasi sekaligus pemilik dari taman bacaan Kampung Buku menyebutkan bahwa "Kebijakan seleksi tidak tertulis. Pembuatan kebijakannya dilakukan oleh saya sendiri dan untuk poin kebijakan seleksinya hanya seleksi untuk buku yang masuk adalah bukubuku non pelajaran".

Hal ini bertentangan dengan prosedur perpustakaan pada umumnya seperti teori yang dikemukakan oleh Reitz dalam Winoto, Sinaga dan Rohanda (2018) yang menyatakan bahwa kebijakan seleksi adalah suatu 
pernyataan resmi secara tertulis dari prinsip-prinsip seleksi perpustakaan, termasuk kriteria dalam membuat seleksi dan keputusan deseleksi yang meliputi bidang yang dicakup, derajat spesialisasi, tingkat kesulitan, bahasa, format, keseimbangan dan lain sebagainya serta kebijakan mengenai hadiah.

Sehingga dapat dikatakan bahwa kebijakan seleksi pada perpustakaan pribadi tidak membuat kebijakan tertulis melainkan poin-poin kriteria seleksi yang dibuat oleh pemilik dan disepakati bersama. Kebijakan seleksi pada perpustakaan pribadi tidak dalam bentuk tertulis melainkan berupa kesepakatan yang berisi poin-poin seleksi dan dibuat oleh pemilik perpustakaan, hal ini pun berlaku di Perpustakaan Kineruku

\section{Seleksi di Perpustakaan Kineruku}

Seleksi di Perpustakaan Kineruku dilakukan setelah kebijakan seleksi kemudian, untuk koleksi yang akan datang dipertimbangkan dengan cara mencocokkan koleksi tersebut dengan kriteria yang Perpustakaan Kineruku gunakan yaitu tema humaniora dan juga selera. Proses mencocokkan koleksi dilakukan oleh pemilik, pengurus serta staf dibantu dengan pencarian koleksi secara daring dan atau pihak Kineruku mencari koleksi fisik untuk di baca isi dari koleksi tersebut.

Kegiatan seleksi pada perpustakaan pribadi dilakukan setelah dibentuknya kebijakan seleksi dan mengikuti kebijakan tersebut serta hanya mengandalkan internet sebagai alat bantu seleksi. Hal ini diperkuat oleh Dimyati (2019) yang merupakan seorang aktivis literasi sekaligus pemilik dari taman bacaan Kampung Buku menyatakan bahwa:

"Seleksi koleksi yang mesti ada di Kampung Buku mengutamakan bukubuku fiksi dan buku-buku non fiksi yg kekinian atau berisi informasi yang abadi. Kemudian kalau ada buku-buku yang judulnya sama itu dikeluarkan atau disumbangkan ke taman baca lainnya. Terus buku-buku yang mengandung unsur pornografi juga tidak masuk ke Kampung Buku. Oh ya, Kampung Buku juga tidak menyimpan buku-buku pelajaran dan kalau untuk alat bantu seleksinya saya biasa menggunakan internet". 
Hal ini sejalan dengan pendapat menurut Laksmi (2015) seleksi adalah proses mengidentifikasi bahan pustaka yang akan ditambahkan pada koleksi yang telah ada di perpustakaan. Kemudian dikuatkan oleh anggapan yang dikemukakan oleh Yulia dalam Winoto, Sinaga dan Rohanda (2018) yang mengelompokkan alat bantu menjadi sembilan kategori yaitu: Katalog penerbit, Bibliografi Nasional Indonesia (BNI), Katalog Induk Nasional, Daftar tambahan koleksi dari perpustakaan lain, Tinjuan dan resensi buku, Indeks, Katalog buku online, GBPP/SAP, dan Narasumber.

Sehingga dapat dikatakan kegiatan seleksi pada perpustakaan pribadi dilakukan mengikuti poin-poin dari kebijakan seleksi yang sudah dibuat oleh pemilik. Kemudian Perpustakaan Kineruku hanya menggunakan salah satu alat bantu yaitu katalog buku online atau pencarian daring dalam pelaksanaan kegiatan seleksi karena semakin mudahnya akses internet.

\section{Pengadaan Bahan Pustaka di Perpustakaan Kineruku}

Pengadaan bahan pustaka di Perpustakaan Kineruku menggunakan dua metode pengadaan bahan pustaka yaitu melalui pembelian pribadi dan sumbangan/hadiah dari kerabat pemilik Kineruku. Alur Kineruku menggunakan metode pembelian pribadi dengan dana pribadi, dimulai dengan mencari tahu toko buku seperti Gramedia dan Periplus yang menjual koleksi yang diinginkan dan apabila di toko buku tersebut tidak ada, biasanya Perpustakaan Kineruku membeli di toko buku lain dan alur tersebut juga berlaku untuk koleksi Perpustakaan Kineruku yang berbahasa asing.

Alur pengadaan bahan pustaka di Perpustakaan Kineruku menggunakan metode sumbangan/hadiah dimulai dengan pihak yang ingin menyumbangkan mengabarkan pihak Perpustakaan Kineruku kemudian pihak Perpustakaan Kineruku menyeleksi koleksi tersebut apabila sesuai dengan tema dan selera Perpustakaan Kineruku serta tersedianya ruang untuk menyimpan koleksi tersebut akan Perpustakaan Kineruku terima namun, apabila tidak sesuai Perpustakaan Kineruku akan mengabarkan pihak penyumbang. 
Kegiatan pengadaan bahan pustaka pada perpustakaan pribadi menggunakan dua metode yaitu pembelian dengan menggunakan dana pribadi dan sumbangan/hadiah dari pemustaka atau donatur. Hal ini diperkuat oleh pernyataan Dimyati (2019) bahwa: "Pengadaan dari membeli, Namun sebagian besar...hampir 95\% berasal dari sumbangan. Kalau ada sumbangan langsung diserahkan ke Kampung Buku atau pihak kita yang jemput untuk menerima koleksi tersebut".

Hal ini sejalan dan sesuai dengan prosedur yang ada pada perpustakaan pada umumnya dengan perpustakaan pribadi seperti yang diungkapkan oleh Winoto, Sinaga dan Rohanda (2018) bahwa pengadaan bahan pustaka adalah sebuah rangkaian dalam proses pengembangan koleksi yang berupa perolehan dan penerimaan bahan pustaka yang berupa fisik maupun akses ke sumber daya online.

Serta prosedur pengadaan bahan pustaka di perpustakaan pribadi sudah sesuai dengan prosedur yang ada pada perpustakaan pada umumnya diperkuat dengan pendapat Yulia dan Sunana (2018) yang menyebutkan bahwa pengadaan bahan pustaka dapat dilakukan dengan cara: "Pembelian, Sumbangan atau Hibah dan, Tukar menukar koleksi dengan perpustakaan lain".

Sehingga dapat dikatakan bahwa kegiatan pengadaan bahan pustaka di Perpustakaan Kineruku berjalan untuk memperoleh dan menerima koleksi untuk perpustakaan dengan menggunakan metode, yaitu pembelian dan sumbangan/hibah. Untuk metode pembelian, Perpustakaan pribadi membeli langsung ke toko buku menggunakan dana pribadi dan untuk metode sumbangan/hibah perpustakaan pribadi mendapatkan sumbangan langsung dari donatur.

\section{Penyiangan di Perpustakaan Kineruku}

Prosedur kegiatan penyiangan di Perpustakaan Kineruku adalah mereparasi buku seperti memberikan selotip pada koleksi yang tingkat kerusakannya kecil hingga memberi sampul pada buku menjadi hal yang paling sering dilakukan pada kegiatan penyiangan di Perpustakaan 
Kineruku Selain itu juga dalam pelaksanaan penyiangan Perpustakaan Kineruku belum menggunakan tenaga ahli, Perpustakaan Kineruku juga belum memiliki gudang penyimpanan dan menggunakan ruangan pribadi pemilik sebagai tempat penyimpanan koleksi yang tidak terpakai serta Perpustakaan Kineruku sendiri tidak memiliki waktu khusus dalam melakukan proses penyiangan. Hal-hal tersebut ada dikarenakan Perpustakaan Kineruku masih terpaku pada situasi dana, ketersediaan tempat dan waktu.

Kegiatan penyiangan pada perpustakaan pribadi dilakukan pada koleksi perpustakaan yang kondisi fisiknya saja yang mengalami kerusakan dan prosedur yang dilakukan adalah memperbaiki sebisa mungkin oleh pihak perpustakaan. Dikuatkan dengan pernyataan oleh Dimyati (2019) bahwa "Kalau ada buku-buku yang rusak pilihannya diperbaiki sedikit lalu kami sumbangkan. Kalau rusaknya parah kita kilo ke pengepul dan beli baru dengan judul yang sama".

Hal ini sejalan dengan pendapat yang dikemukakan oleh Johnson dalam Winoto, Sinaga dan Rohanda (2018) yang menyatakan bahwa penyiangan adalah proses menghilangkan bahan dari koleksi aktif yang berupa penarikan atau pemindahan serta ada beberapa alasan dilakukannya penyiangan bahan pustaka di suatu lembaga perpustakaan diantaranya:

1) Bahan pustaka tersebut sudah dalam kondisi rusak sehingga perlu untuk dikeluarkan dari tempatnya penyimpanan.

2) Informasi yang dikandung dalam bahan pustaka tersebut sudah usang atau tidak up-to-date. Jenis koleksi seperti ini biasanya terdapat pada koleksi untuk subjek teknologi informasi dan subjek ilmu tertentu yang perkembangan pesat seperti buku tentang komputer dan perangkat lunak.

Sehingga dapat dikatakan bahwa kegiatan penyiangan di Perpustakaan Kineruku dilakukan melihat suatu koleksi keadaan fisiknya saja. Kegiatan penyiangan dengan kriteria fisik adalah apabila fisik bahan pustaka sudah rusak seperti jilidnya lepas, halaman sobek, urutan halaman sudah tidak lengkap, tintanya sudah pudar, kertasnya sudah kena rayap, dan lain-lain. 


\section{Evaluasi di Perpustakaan Kineruku}

Kegiatan evaluasi di Perpustakaan Kineruku dilakukan ketika rapat formal bersama staf dengan waktu yang tidak terjadwal dan aspek yang dimasukan kedalam evaluasi adalah pencapaian visi dan misi yaitu berbagi koleksi dan menyediakan referensi koleksi, dan interakasi dengan pemustaka. Serta Perpustakaan Kineruku tidak memiliki visi dan misi yang tertulis melainkan poin-poin yang disepakati bersama.

Lain halnya dengan Perpustakaan Kineruku melakukan evaluasi berdasarkan visi dan misi yang berisi poin-poin kesepatakan bersama, Kampung Buku tidak memiliki standar yang dibahas dalam evaluasi. Dimyati (2019) menyatakan bahwa:

"Sebenarnya tidak ada proses evaluasi yang memiliki standar di Kampung Buku. Hanya dari buku-buku yg sering dipinjam jadi kita tahu tema-tema apa saja yang mesti dimiliki oleh Kampung Buku. Kemudian mengevaluasi buku-buku terbitan lama yang tidak dipertahankan untuk dikeluarkan”.

Kedua hal ini sebetulnya sudah sejalan dengan pernyataan Winoto, Sinaga dan Rohanda (2018) yang menyebutkan bahwa evaluasi koleksi adalah kegiatan yang berkaitan dengan menentukan kekuatan dan kelemahan dari koleksi bahan pustaka dilihat dari aspek keterkaitan dengan visi dan misi perpustakaan dan lembaga penaungnya, kebutuhan dan selera masyarakat pengguna baik pengguna aktif maupun pengguna potensial.

Sehingga dapat dikatakan bahwa kegiatan evaluasi di perpustakaan pribadi tidak memiliki standar tertentu, semua tergantung oleh keputusan pemilik perpustakaan pribadi tersebut. Serta apabila di suatu perpustkaan pribadi melakukan kegiatan evaluasi dilakukan hanya untuk mengetahui aspek-aspek yang dibutuhkan oleh perpustakaan tersebut seperti pencapaian visi dan misi dan interaksi dengan pemustaka saja, hal ini pun berlaku di Perpustakaan Kineruku. 


\section{PENUTUP}

\section{Simpulan}

Kesimpulan yang peneliti dapatkan dari hasil dan pembahasan penelitian bahwa: Kebijakan pengembangan koleksi di Perpustakaan Kineruku tidak memiliki kebijakan secara tertulis melainkan hanya kesepakatan bersama dari hasil rapat pemilik dan pengelola.; Analisis pemustaka di Perpustakaan Kineruku dilakukan dengan metode informal, melalui penerimaan saran dan masukan pemustaka terkait koleksi yang dibutuhkan.; Kebijakan seleksi di Perpustakaan Kineruku tidak memiliki dokumen tertulis terkait kebijakan melainkan kesepakatan bersama dari pemilik dan pengurus Perpustakaan Kineruku, dengan poin-poin yaitu memilih koleksi yang bertemakan humaniora serta selera dari pemilik dan pengurus Kineruku sendiri.; Seleksi di Perpustakaan Kineruku menggunakan kesepakatan bersama dari pemilik dengan pengurus yang berfokus pada tema humaniora dengan alat bantu seleksi katalog buku online atau pencarian daring.; Pengadaan bahan pustaka di Perpustakaan Kineruku menggunakan dua metode pengadaan bahan pustaka yaitu melalui pembelian langsung ke toko buku dengan dana pribadi pemilik dan sumbangan/hadiah dari kerabat pemilik Perpustakaan Kineruku.; Penyiangan di Perpustakaan Kineruku tidak memiliki dokumen kebijakan khusus mengenai kegiatan penyiangan serta kegiatan penyiangan di Perpustakaan Kineruku hanya sebatas memperbaiki kerusakan fisik pada koleksi saja.; Evaluasi di Perpustakaan Kineruku dilakukan ketika rapat formal bersama staf dengan waktu yang tidak terjadwal dengan melihat aspek kekuatan dan kelemahan koleksi yang dimiliki Perpustakaan Kineruku dikaitkan dengan visi dan misi serta kebutuhan pemustaka.

\section{Saran}

Terkait kebijakan dan proses kegiatan pengembangan koleksi yang belum berjalan secara formal dan tertulis, alangkah lebih baik jika Perpustakaan Kineruku membuat kebijakan pengembangan koleksi serta kebijakan seleksi tertulis yang bisa berfungsi sebagai perencanaan dan 
pedoman pengembangan koleksi. Kemudian alat bantu seleksi, Perpustakaan Kineruku sebaiknya tidak hanya mengandalkan katalog buku online sebagai alat bantu, alangkah lebih baik apabila Perpustakaan Kineruku menambahkan alat bantu seleksi seperti katalog penerbit, tinjuan dan resensi buku, dan narasumber yang bisa dipercaya untuk menjadi alat bantu seleksi. Perpustakaan Kineruku dalam penyiangan sebaiknya tidak hanya memperhatikan kondisi fisik koleksinya saja, namun juga memperhatikan nilai keusangan informasi yang ada di dalam koleksi tersebut. 


\section{DAFTAR PUSTAKA}

Dimyati, E. (2019). "Wawancara Triangulasi." Wawancara via E-mail oleh penulis. April 25, 2019.

Dimyati, E. (2019). "Wawancara Triangulasi." Wawancara via E-mail oleh penulis. September 3, 2019.

Evans, E. (2005). Developing Library \& Information Center Collection. Colorado: Libraries Unlimited.

Laksmi. (2015).Modul Pengembangan koleksi. Jakarta: Universitas Terbuka.

Moleong, L. J. (2007). Metodologi Penelitian Kualitatif. Bandung: Remaja Rosdakarya.

Sulistyo-Basuki. Pengantar Ilmu Perpustakaan. Jakarta: Gramedia Pustaka Utama, 1991.

Winoto, Yunus, Dian Sinaga, dan Rohanda. Dasar-Dasar Pengembangan Koleksi. Kebumen: Intishar Publishing, 2018.

Yin, R. K. (20014). Studi kasus desain dan metode. Jakarta : Raja Grafindo Persada

Yulia, Y., \& Sujana, J. G. (2009). Pengembangan Koleksi. Jakarta:

Universitas Terbuka.

Winoto, Y., Sinaga, D, dan Rohanda. (2018). Dasar-Dasar Pengembangan Koleksi. Kebumen: Intishar Publishing. 